\title{
Observations on white-tailed deer and habitat response to livestock grazing in south Texas
}

\author{
WILL E. COHEN, D. LYNN DRAWE, FRED C. BRYANT, AND LISA C. BRADLEY
}

\section{Abstract}

Since short duration grazing (SDG) was introduced to Texas, concern for white-tailed deer (Odocoileus virginianus) has magnified because they are a species of major economic importance to ranchers. The objective of this study was to observe the effects of SDG and continuous yearlong grazing (CG) on home ranges and movement indices of female deer, and on forage availability. The study was conducted on the Rob and Bessie Welder Wildlife Refuge, near Sinton, Texas. The study area included a 10-pasture SDG cell and a CG pasture, each stocked at $2.8 \mathrm{ha} / \mathrm{auy}$. Cattle grazed each SDG paddock 2 to 8 days; paddocks were rested 32 to 47 days. A total of 3,861 radio-fixes from 11 does was collected over an 11-month study period in 1983. Monthly and annual home ranges of does were similar $(P>0.05)$ between SDG (207 ha) and CG (229 ha). However, white-tailed deer traveled 35\% more $(P<0.05)$ between fixes in SDG $(449 \mathrm{~m})$ than in CG $(332 \mathrm{~m})$ from May to August, a time of greatest physiological and nutritional stress for female deer in south Texas. Also, does avoided $(P<0.05)$ cattle during 2 cycles of the SDG rotation. The primary trend observed was for the deer under SDG to avoid cattle concentrations by alternating between preferred habitats rather than a predictable paddock-to-paddock movement. In general, there were few differences in total grass and forb cover between SDG and CG. However, several forage species important to deer were less frequent $(\boldsymbol{P}<0.05)$ under SDG than $C G$.

Key Words: continuous grazing, home range, movement indices, Odocoileus virginianus, radio telemetry, short duration grazing

Over the last 30-40 years, dramatic changes have taken place in Texas grazing management. Initially, continuous grazing (CG), where animals dictated their own patterns of use, was most common. In the 1950's and 1960's, those at the forefront in grazing management in Texas shifted from continuous grazing to multiherd, multi-pasture management programs such as the Merrill 3-herd, 4-pasture regimen (Bryant et al. 1982). By 1961, a 1-herd, multi-pasture approach to non-selective grazing was introduced (Howell 1978). This approach reached Texas in the late 1960's with the high-intensity, low-frequency (HILF) regimen, a variation of nonselective grazing (Acocks 1966). Short duration grazing (SDG), requiring shorter grazing periods, shorter rest periods, and more grazing cycles per year than HILF (Bryant et al. 1982), emerged in the mid- to late 1970's. Generally, SDG has grazing periods of 7 days or less, rest periods from 30 to 60 days, and grazing cycles short enough to allow 6 or more rotations per year (Savory 1979).

Livestock, vegetation, and soil responses to SDG in Texas are well documented (Heitschmidt et al. 1982a, 1982b, 1982c); however, data on white-tailed deer(Odocoileus virginianus) response to

Authors are research assistant, Range Science Department, Utah State University, Logan 84322; assistant director, Welder Wildlife Foundation, PO Drawer 1400 Sinton, Tex. 78387; and professor and technician, Dept. of Range and Wildlife Management, Texas Tech University, Lubbock 79409. At the time of the research, the senior author was research assistant, Dept. of Range and Wildlife Management, Texas Tech University, Lubbock.

Research was funded by the Rob and Bessie Welder Wildlife Foundation, Sinton, Tex., as WWF Contribution No. 333. This is Technical Article T-9-520 of the College of Agricultural Sciences, Texas Tech University. Authors would like to thank D. Wester and $L$. Folse for assistance in statistical and telemetry analyses, respectively Manuscript accepted 23 January 1989.
SDG are relatively few. Guynn and White (1984) found no difference in deer densities between SDG and a 3-herd, 4-pasture grazing regimen.

We compared home range sizes and movement indices of adult female white-tailed deer between a SDG and a CG pasture; evaluated deer locations relative to cattle rotation through the SDG cell; and compared vegetation responses between SDG and CG.

\section{Study Area}

The study was conducted on the Rob and Bessie Welder Wildlife Foundation Refuge near Sinton, Texas. The refuge comprises 3,157 ha of native rangeland adjacent to the Aransas River in San Patricio County. It is located in the Coastal Bend region, a transitional zone between the Gulf Prairies and Marshes and the South Texas Plains (Gould 1975).

Prior grazing history of the SDG site was a HILF system stocked at a moderate rate of 5.7 ha/animal unit year (auy) for 8 years, while the CG pasture was continuously grazed at a stocking rate of $5.7 \mathrm{ha} /$ auy for 8 years (Drawe and Cox 1978). In 1982, SDG was initiated and stocking was increased to $2.8 \mathrm{ha}$ / auy; the CG pasture was maintained under continuous yearlong grazing, but at the identical stocking rate ( $2.8 \mathrm{ha} / \mathrm{auy})$ of SDG.
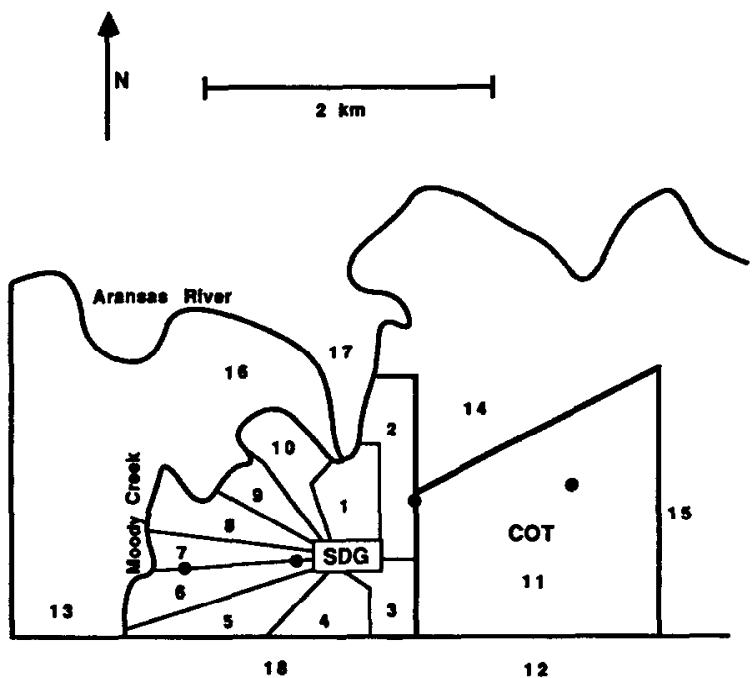

Fig. 1. The short-duration grazing (SDG) cell (Locations 1-10), continuous grazing (CG) pasture (Location 11), and other areas of female white-tailed deer use (Locations 12-18). $\bullet=$ tracking station location. Grazing rotations on the SDG cell began in Location 10 and proceeded clockwise.

The SDG cell consisted of 219 ha sub-divided into 10 equal-sized paddocks (Fig. 1). Water, salt, and supplemental feed were located in the cell center, but livestock also had access to water from the Aransas river and Moody Creek, which bordered the SDG cell on the west and north. Each SDG paddock was grazed from 2 to 8 days and rested 32 to 47 days, depending on vegetation response. 
Table 1. Mean monthly $95 \%$ ellipse home ranges (ha), based on monthly activity centers, of female deer under a short duration and continuous grazing on the Welder Widdife Refuge, 1983.

\begin{tabular}{|c|c|c|c|c|c|c|c|c|c|c|c|c|}
\hline \multirow{2}{*}{\multicolumn{2}{|c|}{ Grazing system }} & \multicolumn{11}{|c|}{ Month } \\
\hline & & Feb & Mar & Apr & May & Jun & Jul & Aug & Sep & Oct & Nov & Dec \\
\hline$\overline{\text { SDG }}$ & $\begin{array}{l}\bar{x}^{1} \\
\text { SE } \\
n^{2}\end{array}$ & $\bar{Z}$ & $\begin{array}{r}419 \\
14 \\
3\end{array}$ & $\begin{array}{r}316 \\
5 \\
3\end{array}$ & $\begin{array}{r}175 \\
13 \\
3\end{array}$ & $\begin{array}{r}186 \\
44 \\
4\end{array}$ & $\begin{array}{r}233 \\
115 \\
3\end{array}$ & $\begin{array}{r}151 \\
9 \\
2\end{array}$ & $\begin{array}{r}193 \\
68 \\
4\end{array}$ & $\begin{array}{r}162 \\
15 \\
3\end{array}$ & $\begin{array}{r}92 \\
20 \\
?\end{array}$ & $\begin{array}{r}143 \\
37 \\
?\end{array}$ \\
\hline CG & $\begin{array}{l}\ddot{\bar{x}} \\
\text { SE } \\
\mathbf{n}\end{array}$ & $\begin{array}{r}323 \\
55 \\
5\end{array}$ & $\begin{array}{r}440 \\
66 \\
6\end{array}$ & $\begin{array}{r}545 \\
152 \\
5\end{array}$ & $\begin{array}{r}179 \\
63 \\
3\end{array}$ & $\begin{array}{r}109 \\
21 \\
5\end{array}$ & $\begin{array}{r}137 \\
37 \\
3\end{array}$ & $\begin{array}{r}100 \\
37 \\
3\end{array}$ & $\begin{array}{r}145 \\
1 \\
2\end{array}$ & $\begin{array}{r}158 \\
33 \\
4\end{array}$ & $\begin{array}{r}160 \\
26 \\
3\end{array}$ & $\begin{array}{r}221 \\
74 \\
4\end{array}$ \\
\hline
\end{tabular}

${ }^{1}$ Means within months were not significantly $(P>0.10)$ different.

$2 \mathbf{n}=$ number of deer.

The 253-ha CG pasture had water, salt, and feeding facilities available at 2 locations.

\section{Methods}

\section{Deer Home Range and Movement Indices}

Radio telemetry was used to monitor white-tailed deer home ranges and movements in the SDG cell and CG pasture. In the winter of 1982-83, drop nets were used to capture 8 and 10 female deer in the SDG cell and CG pasture, respectively. Deer were fitted with radio collars and cattle ear tags, and weights and ages were recorded. After deer losses from death or movement off the area, sufficient data for analysis were obtained on 6 adult female deer in the SDG cell and 5 adult female deer in the CG pasture.

Deer were monitored from 6 February to 31 December 1983 using a null radio telemetry system (Hallberg et al. 1974). Each deer was located from 3 permanent tracking stations, 4 times/day (dawn, noon, dusk, 2300 hours), for 5 consecutive days. Each 5-day sampling period was separated by 5 days of no tracking, resulting in approximately 60 fixes per month for each deer.

Triangulation of 3 azimuths was used to plot locations for each animal. Accuracy of the telemetry system was estimated as $\pm 2^{\circ}$. A location was deemed unreliable and excluded from data analysis if the area of the error polygon (Springer 1979) was $\geq 1.3$ ha. A total of 3,861 radio-fixes were used in analysis. Mean size of all acceptable error polygons was $0.2 \mathrm{ha}$. All reliable fixes were within $1.6 \mathrm{~km}$ of their respective tracking stations.

Monthly home ranges were determined by the $95 \%$ ellipse technique (Jennrich and Turner 1969). A one-way analysis of variance was used to test for differences between home range sizes of deer with activity centers (Hayne 1949) in the SDG cell or the CG pasture.

To compare relative movements of deer within the SDG cell and CG pasture, deer fixes were plotted on a map overlay of the study area. Movement indices for individual deer were determined by summing distances between successive fixes in each 5-day sample period. Monthly means were computed for each deer within a grazing treatment by summing distance data across each 5-day sampling period within a month and dividing by the total number of fixes for that month. Means were compared using a one-way ANOVA.

\section{Deer Response to Cattle Rotation}

Deer response to movement of the cattle herd under SDG was determined based on deer distribution frequency tables comparing deer locations relative to the paddock cattle occupied within each complete grazing cycle. The independent variable in the frequency distribution tables was cattle location; dependent variables were potential deer locations and presence/absence of deer in any 1 of 18 potential locations, both inside and outside the SDG cell (Fig. 1). A G-test was used to determine if deer significantly $(\alpha=0.05)$ responded to cattle during the rotation by testing for homogeneity of deer frequency distributions among cattle locations (Kullback 1959).

\section{Deer Habitat}

Vegetative cover and frequency were monitored monthly on the SDG cell and CG pasture. Only those grass and forb species which comprised $2 \%$ or more of deer diets on the Welder Wildlife Refuge (Kie et al. 1980) were measured. Woody vegetation was not sampled because of its low occurrence in deer diets (Chamrad and Box 1968, Kie et al. 1980).

Cover and frequency were measured using six $0.10-\mathrm{m}^{2}$ rectangular quadrats placed at random intervals along each of 10 random transects in each grazing treatment. Cover was estimated, to the nearest $1 \%$, by species by quadrat (Daubenmire 1959). Mean cover was calculated by month and compared between treatments using a one-way ANOVA. Frequency of occurrence was calculated monthly by dividing the number of quadrats containing a particular species by the total number of quadrats. Chi-square analysis was used to compare species frequency between SDG and CG.

Because of the size and nature of this experiment, the SDG and CG programs could not be replicated. Therefore, animal and vegetational variances within treatments were used for analyses. This approach is considered valid when time and cost preclude replication of a large experiment (Hurlbert 1984, Guthery 1987).

Table 2. Mean movement indices ( $m$ ) for female deer captured in the short duration grazing cell and the continuously grazed pasture on the Welder Wildlife Refuge, 1983.

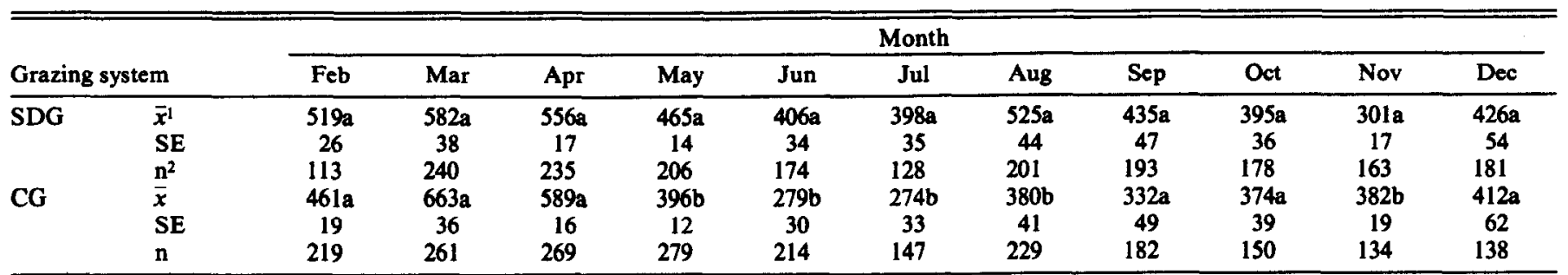

TMeans within months were not significantly $(P>0.05)$ different.

$\mathbf{2} \mathbf{n}=$ number of fixes. 

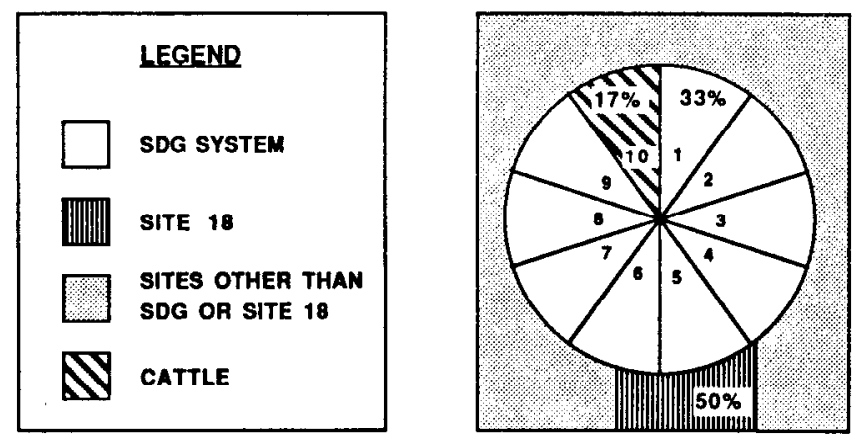

$N=12$

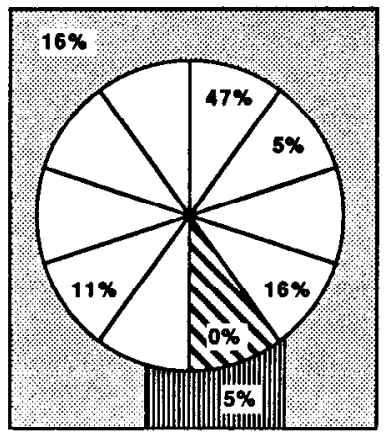

$N=19$

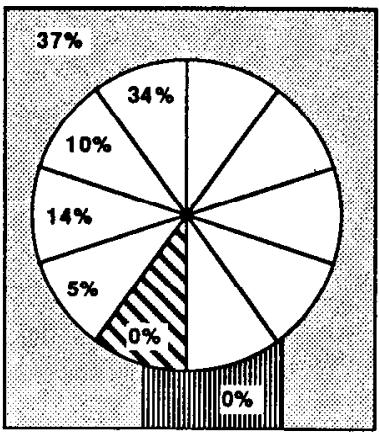

$N=21$

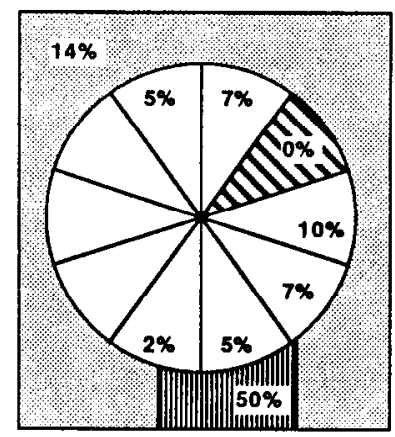

$N=42$

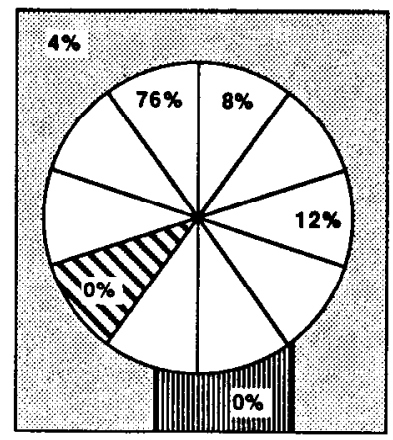

$\mathbf{N}=25$

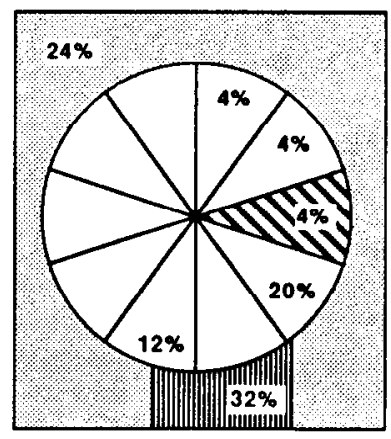

$N=25$

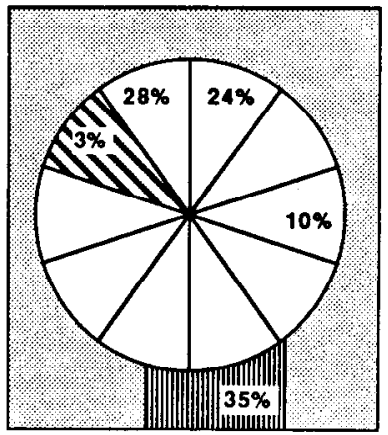

$\mathbf{N}=\mathbf{2 9}$

Fig. 2. Schematic diagrams illustrating the significantly $(\mathrm{P}<0.05)$ correlated distributions of female deer locations relative to cattle location on the SDG cell at the Welder Wildlife Refuge. Successive diagrams indicate distributions on 8 March, 9-12 March, 18-20 March, 21-22 March, 28-29 March, 30 March-1 April, and 7-9 April, 1983. $N=$ number of deer locations.

\section{Results and Discussion}

\section{Deer Home Range and Movement Indices \\ Home Range}

Monthly deer home ranges were similar $(P>0.10)$ between the SDG cell and CG pasture (Table 1). Large standard errors of the means indicated large variability during some months in home range size among individual deer. On a HILF grazing treatment, Adams (1978) found high stocking rates of livestock did not cause deer on the Welder Refuge to abandon their home ranges. Our radio-collared deer also showed fidelity to their home ranges during this study, regardless of grazing treatment and even though cattle stocking rates were relatively high ( $2.8 \mathrm{ha} /$ auy) in both SDG and $\mathrm{CG}$.

Mean home range size in this study was 218 ha. Inglis et al. (1979) reported a mean home range size of 84 ha for 25 does on the Welder Refuge, based on data collected from 1966 to 1970 . During that period, the Refuge was only lightly grazed (7.2-7.7 ha/auy) by steers, and deer densities were $44 \%$ higher than 1982-1983 densities. Thus, intensive grazing programs and higher stocking rates or deer densities may have affected home range sizes on the Refuge. These hypotheses demand further investigation to determine the long-term relationships between white-tailed deer densities, home range sizes, and livestock grazing in south Texas.

\section{Movement Indices}

Examination of mean distances between fixes indicated deer traveled more during March and April than other months in both SDG and CG (Table 2). This peak corresponded with rapid vegetation growth during spring green-up and appears unusual since forage availability would be greatest at this time. Deer traveled least during early summer and fall on SDG and CG, with moderate travel during winter.
Throughout the entire 11-month study period, average distance between fixes was $10 \%$ greater under SDG than CG. Deer traveled significantly farther between fixes $(P<0.05)$ under SDG than CG during May, June, July, and August (Table 2). The greatest differences were in June and July when deer traveled $46 \%$ and $45 \%$ farther between fixes, respectively, in SDG than CG, while the May to August average was $35 \%$ greater.

Deer are well adapted for energy conservation, but any disturbance which alters behavior can potentially depress productivity. Moen (1978) found white-tailed deer have their lowest metabolism in winter and their highest in summer. Fetal growth increases rapidly during late gestation (Verme 1963). Energy demands for the doe are at their highest level during the first 2 months of lactation (Moen 1978). Thus, late pregnancy and early lactation result in increased energy demands. This period of high energy demands by deer at the Welder Wildlife Refuge occurs in April and May (late gestation) and June and July (early lacatation). The observed increase in distance moved by female deer on the SDG cell during these physiologically important months warrants further investigation. In particular, studies of deer energy intake and expenditure under SDG are necessary to determine if increased activity during spring and summer negatively affects reproduction.

\section{Deer Response to Cattle Rotation}

Deer avoided $(P<0.05)$ cattle as the herd moved through the SDG cell in 2 of the 8 grazing cycles during 1983. These significantly correlated grazing cycles were from 8 March to 9 April 1983 (Fig. 2), and from 17 May to $17 \mathrm{June} 1983$ (Fig. 3). Deer responded to cattle during the grazing cycle from 10 April to 16 May by moving their activity centers off the SDG cell and the Refuge to site 18. Radio fixes taken on deer did not always coincide with cattle presence in every paddock of the SDG cell. Thus, data were not 

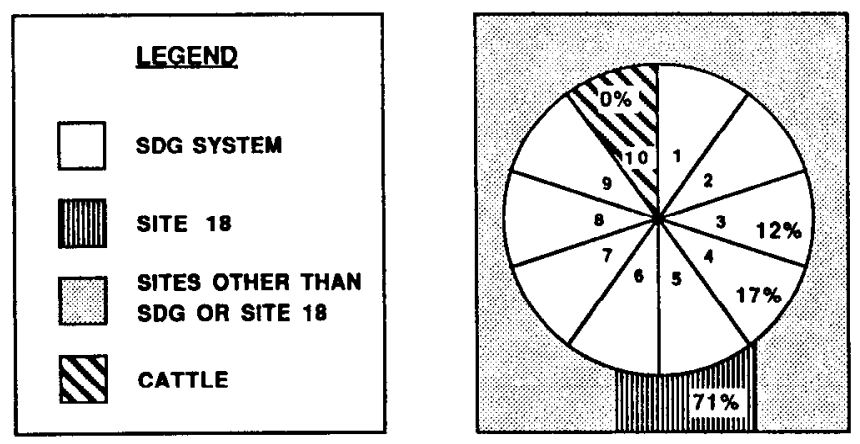

$N=24$

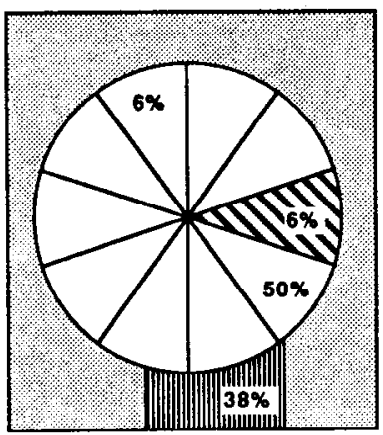

$N=\mathbf{3 2}$

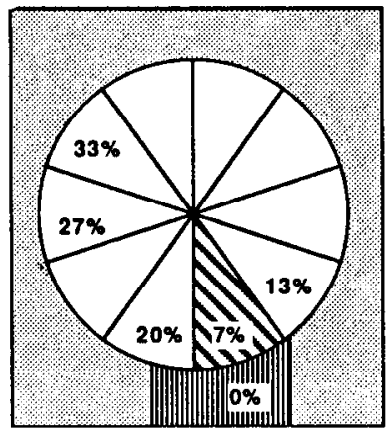

$N=15$

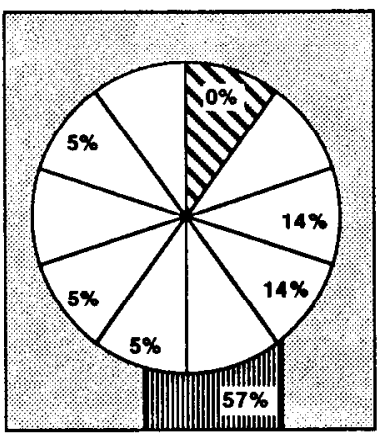

$\mathbf{N}=\mathbf{2 1}$

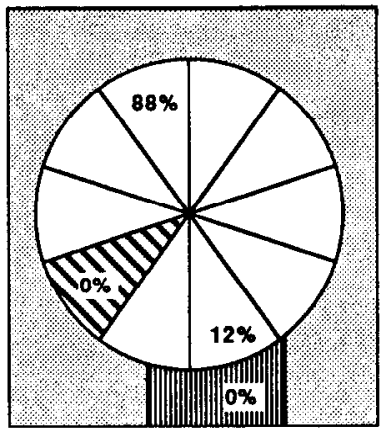

$\mathbf{N}=\mathbf{2 4}$

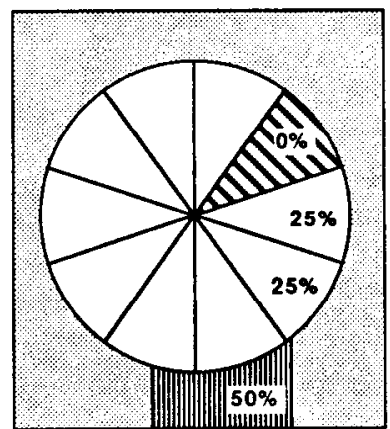

$N=12$

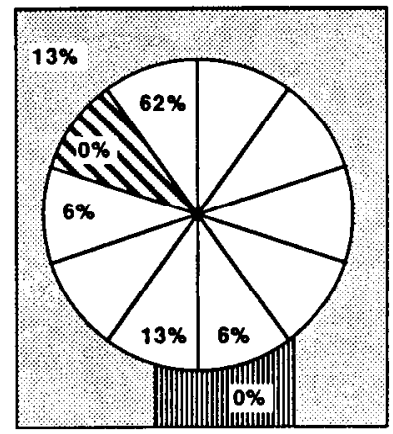

$N=16$

Fig. 3. Schematic diagrams illustrating the significantly $(\mathrm{P}<0.05)$ correlated distributions of female deer locations relative to cattle location on the $S D G$ cell at the Welder Wildlife Refuge. Successive diagrams indicate distributions on 17-18 May, 19-21 May, 27 May, 28-31 May, 6-7 June, 8-10 June, and 16-17 June, 1983. $N=$ number of deer locations.

available on deer when cattle were in paddocks 1,4 , and 8 of the March-April cycle and paddocks 4, 6, and 8 of the May-June cycle.

Behavioral patterns during both grazing cycles indicated deer preferred to position themselves off the SDG cell at site 18 whenever cattle were in paddocks $10,1,2$, and 3 (Figs. 2 and 3). Site 18 was on an adjacent ranch that was grazed continuously yearlong at approximately $4.0 \mathrm{ha} /$ auy, a relatively heavy rate. Fidelity for this site diminished as the cattle herd moved clockwise from paddock 10 to paddock 3. Cattle presence in paddocks 5,6 , or 7 caused a dramatic shift in deer distribution as they avoided site 18 and deer moved to paddocks $8,9,10$, and 1 on the north side of the SDG cell. Thus, deer showed fidelity for 2 major sites and shifted back and forth as cattle approached either site. Although there was a secondary trend for deer to concentrate in paddocks 3 and 4, immediately in front of cattle rotation (Figs. 2 and 3), the primary trend was for the deer under SDG to avoid cattle concentrations by alternating between preferred habitats rather than a consistent paddock-to-paddock movement.

Although deer commonly used site 18 , they consistently returned to the SDG cell. The apparent preference of the deer for the SDG cell may have been a consequence of fidelity to their home ranges or a preference for some particular aspect (i.e., forage, cover, lack of hunting) of the Refuge or the cell, but these hypotheses could not be tested in this study. Behavioral studies of the factors influencing site fidelity in white-tailed deer are suggested.

Adams (1978) and Kruger (Welder Wildlife Refuge progress report), studying deer response to HILF on the Welder Wildlife Refuge, felt social intolerance of deer for cattle may have caused some movement out of paddocks. McMahan (1966) and Kramer (1973) found deer clearly avoided livestock. Therefore, deer avoidance of cattle under SDG is not surprising.

\section{Deer Habitat}

Five grass species and 13 forb species designated as important to deer (Kie et al. 1980) were monitored from February to December 1983 on the SDG cell and CG pasture. Two important deer forage species, lazy daisy (Aphanostephus ramossissimus) and ironweed (Vernonia texana), were not encountered in either SDG or CG, while purple lovegrass (Eragrostis spectabilis) and orange zexmenia (Zexmenia hispida) were found only during 1 month's sampling. Thus, cover and frequency trends are reported for 14 forage species.

Monthly percent cover was similar $(P>0.05)$ between the 2 areas throughout the study period for doveweed (Croton monanthogynus), bladderpod (Lesquerella argyraea), evening primrose (Oenothera speciosa), Texas frogfruit (Phyla incisa), prairie coneflower (Ratibida columnaris), Texas wintergrass (Stipa leucotricha), snoutbean (Rhynochosia minima), rescuegrass (Bromus unioloides), and sedge (Carex brittoniana). Percent cover was greater $(P<0.05)$ on the CG pasture for western ragweed (Ambrosia psilostachya) during November, false mallow (Malvastrum aurantiacum) during July, wood sorrel (Oxalis dillenii) during October, vine mesquite (Panicum obtusum) during June through October, and common frogfruit (Phyla nodiflora) during April through September and November. During all other months of the study percent cover of these species was similar $(P>0.05)$ on the 2 sites. No species was greater in monthly percent cover on the SDG cell during this study.

Generally, forage species important to deer were more common in the CG pasture, allowing greater opportunity for deer to encounter key food plants. Monthly percent frequency was greater $(P<0.05)$ on the $C G$ pasture for western ragweed during March and November, false mallow during May, July, and August, evening primrose during November, wood sorrel during October, Texas frogfruit during February and November, common frogfruit during March through December, rescuegrass during February through April and December, sedge during February, May, and December, and vine mesquite during May through November. Percent fre- 
quency was greater $(P<0.05)$ on the SDG cell for bladderpod during December, evening primrose during February through May, and wood sorrel during July. Frequency was similar $(P>0.05)$ between the 2 sites during all other months for the species mentioned above, and for doveweed, prairie coneflower, snoutbean, and Texas wintergrass throughout the study.

Kie et al. (1980) found rescuegrass, Panicum spp., and Texas wintergrass to be the most important grass species in adult deer diets on the Welder Wildlife Refuge. Rescuegrass (important in deer diets during late winter and early spring) and vine mesquite (late summer through early spring) both were more common on the CG pasture during these periods. Texas wintergrass, an important winter forage, was equally common on the 2 areas. Kie et al. (1980) reported false mallow was the most important forage species in deer diets on the Refuge, particularly during summer through late fall. This species was most common on the CG pasture during summer and equally common on SDG and CG throughout the rest of the year. Among the forbs, other important species in deer diets were western ragweed (summer) and prairie coneflower (early spring through summer). These species were equally common on the 2 areas during these periods.

\section{Conclusions}

We found female white-tailed deer traveled slightly farther between radio fixes on a SDG cell than under CG over the year. During the late spring and summer, distances between radio fixes were significantly $(P<0.05)$ greater under SDG. Thus, SDG could increase energy demands during periods of gestation and fawnraising, but the level, if any, at which added travel depressed reproduction is unknown. In the spring and early summer, deer clearly avoided SDG paddocks where cattle were concentrated. In general, there was no difference in monthly vegetative cover between SDG and CG. However, several forage species important to deer were less common under SDG than CG.

\section{Literature Cited}

Acocks, J.P.H. 1966. Non-selective grazing as a means of veld reclamation. Proc. Grassi. Soc. So. Afr. 1:33-39.

Adams, N.E. 1978. The effects of cattle on white-tailed deer distribution. M.S. Thesis, Texas A\&I Univ., Kingsville.

Bryant, F.C., F.S. Guthery, and W.M. Webb. 1982. Grazing management in Texas and its impact on selected wildlife, p. 94-112. In. J.M. Peek and P.D. Dalke (eds.), Wildlife-livestock relationships symposium proceedings 10. Univ. Idaho, For., Wildl., and Range Exp. Sta., Moscow.

Chamrad, A.D., and T.W. Box. 1968. Food habits of white-tailed deer in south Texas. J. Range Manage. 21:158-164.

Daubenmire, R. 1959. A canopy-coverage method of vegetational analysis. Northw. Sci. 33:43-64.
Drawe, D.L., and J.E. Cox. 1978. A coordinated range research program for the Welder Wildlife Foundation Refuge, p. 34-43. In: D.L. Drawe (ed.), Ist Welder Wildlife Foundation Symp. Proc., Corpus Christi, Tex. Gould, F.W. 1975. Texas plants, a checklist and ecological summary. Texas Agr. Exp. Sta., Texas A\&M Univ., College Station.

Guthery, F.S. 1987. Guidelines for preparing and reviewing manuscripts based on field experiments with unreplicated treatments. Wildl. Soc. Bull. 15:306.

Guynn, D.E., and L.D. White. 1984. Savory grazing method effect on white-tailed deer in the Edwards Plateau of Texas, p. 80-82. In: T.R. Krausman and N.F. Smith (eds.), Deer in the southwest: a symposium. School of Renewable Natur. Res., Univ. Ariz. Tucson.

Hallbers, D.L., F.J. Janza, and G.R. Trapp. 1974. A vehicle-mounted directional antenna system for biotelemetry monitoring. Calif. Fish and Game 60:172-177.

Hayne, D.W. 1949. Calculation of size of home range. J. Mamm. 30:1-18.

Heitschmidt, R.K., D.L. Price, R.A. Gordon, and J.R. Frasure. 1982a. Short duration grazing at the Texas Experimental Ranch: Effects on aboveground net primary production and seasonal growth dynamics. J. Range Manage. 35:367-372.

Heitschmidt, R.K., R.A. Gordon, and J.S. Bluntzer, 1982b. Short duration grazing at the Texas Experimental Ranch: Effects on forage quality. J. Range Manage. 35:372-374.

Heitschmidt, R.K., J.R. Frasure, P.L. Price, and L.R. Rittenhouse. 1982c. Short duration grazing at the Texas Experimental Ranch: Weight gains of growing heifers. J. Range Manage. 35:375-379.

Howell, L.N. 1978. Development of multi-camp grazing systems in the Southern Orange Free State, Repub. So. Afr. J. Range Manage. $31: 459-465$.

Hurlbert, S.H. 1984. Pseudoreplication and the design of ecological field experiments. Ecol. Monogr. 54:187-211.

Inglis, J.M., R.E. Hood, B.A. Brown, and C.A. DeYoung. 1979. Home range of white-tailed deer in Texas coastal prairie brushland. J. Mamm. 60:377-389.

Jennrich, R.I., and F.B. Turner. 1969. Measurement of non-circular home range. J. Theoret. Biol. 22:227-237.

Kie, J.G., D.L. Drawe, and G. Scott. 1980. Changes in diet and nutrition with increased herd size in Texas white-tailed deer. J. Range Manage. 33:28-34.

Kramer, A. 1973. Interspecific behavior and dispersion of two sympatric deer species. J. Wildl. Manage. 37:288-300.

Kullback, S. 1959. Information theory and statistics. John Wiley and Sons, Inc., New York.

McMahan, C.A. 1966. Suitability of grazing enclosures for deer and wildlife research on the Kerr Wildlife Management Area, Texas. J. Wildl. Manage. 30:151-163.

Moen, A.N. 1978. Seasonal changes in heart rates, activity, metabolism, and forage intake of white-tailed deer. J. Wildl. Manage. 42:715-738.

Savory, A. 1979. Range management principles underlying short duration grazing. Beef Cattle Sci. Handb. 16:375-379. Agr. Serv. Found., Clovis, Calif.

Springer, J.T. 1979. Some sources of bias and sampling error in radio triangulation. J. Wildl. Manage. 43:926-935.

Verme, L.J. 1963. Effect of nutrition on growth of white-tailed deer fawns. Trans. North Amer. Wildl. Nat. Res. Conf. 28:431-443. 